\title{
BARTŁOMIEJ GEMBICKI
}

INSTYTUT SZTUKI, POLSKA AKADEMIA NAUK

\section{EARLY MUSIC RECORDING AS MYTHOGRAPHY - MONTEVERDI AND THE 'OTHER' VESPERS*}

\section{'BRINGING MONTEVERDI'S VESPERS HOME'?}

n I989, John Eliot Gardiner led a performance at St Mark's in Venice of Ves-
pers music by Claudio Monteverdi - preserved in a print from i6ıo - commonly known as the Vespro della Beata Vergine (hereinafter referred to as the 'Vespers I6Io'). In an introductory film to the recording, Gardiner reminds us that the Vespers I6ro were published in a print dedicated to the pope three years before Monteverdi arrived in Venice (1613) to start working as the maestro di cappella at St Mark's church, yet he attempts to prove that there is a particular and not casual connection between Monteverdi's masterpiece and the capital of the Venetian Republic, with its patron's church. Further into the film, we learn a little more about Venice itself, including the special Marian devotion among its residents, and also several other details supposedly linking Monteverdi's Vespers to Venice in general and St Mark's in particular. ${ }^{\mathrm{I}}$ Gardiner goes as far as to describe his performance in Venice as 'bringing Monteverdi's music back to its source'. ${ }^{2}$ This notion perdures in numerous contemporary

* This article summarizes briefly a chapter of my PhD dissertation: Bartłomiej Gembicki, Psalmy, mity i memy. Nieszpory $w$ Wenecji od Willaerta do Gardinera [Psalms, myths and memes: Vespers in Venice from Willaert to Gardiner], Institute of Art of the Polish Academy of Sciences, 2020, pp. I48-23I. I gratefully acknowledge the funding received through the HERA project 'Sound Memories: The Musical Past in Late-Medieval and Early-Modern Europe' (soundme.eu). This project has received funding from the European Union's Horizon 2020 research and innovation programme under grant agreement no. 649307

I Moreover, Gardiner looks for connections between the Vespers I6ro and St Mark's by evoking Islamic connotations. First, he points out elements of the church which remind him of oriental architecture. Then, he states that one can notice the spirit of Islamic gardens in Monteverdi's Vespers.

2 Furthermore, he adds: 'But were the Vespers of Monteverdi performed here in San Marco some time in Monteverdi's lifetime? We simply can't be sure, but it seems almost impossible to believe that they weren't. [...] It seems almost as if the Vespers really belonged here'. Vespers in Venice, directed by Jonathan Fulford, 
musical activities, despite the fact that several musicological studies clearly state that there is no evidence of any connection between the Vespers I6Io and St Mark's. ${ }^{3}$ It is not my aim to ascertain whether in the seventeenth century there was any link between the Vespers of I6IO and St Mark's. Rather I wish to investigate the extent to which Gardiner's (and similar) hypothesises and methods have influenced the contemporary understanding of Monteverdi's I6Io Vespers and of seventeenth-century Vespers music at large. My interest in this issue prompted me to ask what exactly the expression 'Monteverdi's Vespers' makes us think of in the context of music recordings? Which compositions, places, persons or motifs might it bring to mind? And how do record producers 'help' us to connect 'Monteverdi's Vespers' with particular iconographical representations?

In order to answer these questions, I decided to limit my attention to the first thing we (usually) notice when we encounter a music album: its front cover design, which typically consists of two layers: text and iconographic motif(s). Although album covers have received quite a lot of attention in popular music studies, ${ }^{4}$ scholars working on so-called 'early music' have paid little notice to them. ${ }^{5}$ This is designed

BBC 1989. The documentary was later attached to the VHS and DVD editions of the recording issued by Archiv Produktion. In an interview entitled 'Bringing Monteverdi's Vespers home', accompanying the special reedition of the recording issued in 20I7, Gardiner maintains his views: 'I know we can't prove it, but the chances are that, even though Monteverdi wrote the Vespers in Mantua and put the sequence together there, he saw it as a kind of job application for the post of maestro di cappella of St. Mark's. The music fits rather neatly into the peculiar form of liturgy that the Venetians were using at the time - not just the pronounced adoration of the Madonna but the underlying secularity of it. [...] when we did the Vespers there for the first time in 1986, the music seemed to fit the basilica like a glove. The proportions and layout of the building and its amazingly clear but mysterious acoustic, the secrecy of certain areas of the galleries and the side chapels, all contributed towards reflecting or enhancing the ducal scale of the piece - the public, exuberant presentation of the Psalms, and the Canticle, and the private, intimate confessional side of the solo motets. It felt like a homecoming.' Claudio Monteverdi. Vespro della Beata Vergine, John Elliot Gardiner, Archiv Produktion 2017, p. I5. On Gardiner's recording and the documentary, see: Jeffrey Kurtzman, The Monteverdi Vespers of I6I0. Music, Context, Performance, Oxford I999, p. 38.

3 For instance, in June 20I7, the Bath Minerva Choir organized masterclass devoted to the Vespers I6Io, 'written for St Mark's Venice', as we learn from the choir's website: http://bathminervachoir.co.uk/ events/summer-weekend-workshop-and-master-class, accessed 7 June 2019.

4 Jakub Maciej Łubocki, Oktadka jako częśc dokumentu na przyktadzie ptyty gramofonowej w ujęciu bibliologicznym [The cover as part of a document, taking as an example gramophone records from a bibliological perspective], Warsaw 20I7; Steve Jones and Martin Sorger, 'Covering Music. A Brief History and Analysis of Album Cover Design', Journal of Popular Music Studies II (1999), pp. 68-IO2; Marcin Torzecki, Oktadki ptyt. Rzecz o wizualnym uniwersum albumów muzycznych [Record covers: on the visual aspect of music albums], Poznań 2015. An important exception is Kevin Edge, The Art of Selling Songs. Graphics for the Music Business, 1690-1990, London 1991.

5 I have in mind especially the following titles: Richard Taruskin, Text and Act. Essays on Music and Performance, Oxford 1995; Nick Wilson, The Art of Re-enchantment. Making Early Music in the Modern Age, Oxford 2013; John Butt, Playing with History. The Historical Approach to Musical Performance, Cambridge 2002; Bruce Haynes, The End of Early Music. A Period Performer's History of Music for the Twenty-First Century, Oxford 20Io; Elizabeth Upton, 'Concepts of Authenticity in Early Music and Popular Music Communities', Ethnomusicology Review I7 (2012); one important exception is Vincenzo Borghetti, 'Purezza e trasgressione. Il suono del Medioevo dagli anni Cinquanta ad oggi', Semicerchio 44 (20II), pp. 37-54. 
as a small contribution to filling this lacuna and creating awareness of this aspect of the reception of early music.

Leaving aside the debate about the authenticity and historicity of early music performance which has been continuing for decades, ${ }^{6} \mathrm{I}$ will address the influence of phonography on contemporary reception of early music by recalling the concept of myth. This term is not invoked here as referring to a 'fake story' which should be dispelled by means of history and its methodology. It rather takes its inspiration from cultural studies, where the word 'myth' can be understood as a shared 'belief or practice $[\ldots]$ characterized by a certain structure', where its essence is constituted by the repetition of some elements. 7 Therefore, mythography is treated here as a cultural process of ordering (not always intentionally) and giving meaning to particular phenomena. Consequently, certain beliefs are passed on through copying (often with mutations), usually without any verification of their origins. This essay will be devoted to recordings of Monteverdi's Vespers, since they represent nearly 50\% of existing recordings of Vespers polyphonic repertory from the sixteenth to the mid-eighteenth century. This state of things of course attests to the huge disproportion between phonographic recordings and the musical sources preserved in libraries and archives. Conclusions will be based on material encompassing around five hundred albums (including re-releases) produced over the period 1952-2019. ${ }^{8}$ Although some myths will be confronted with the narratives of academic research, it is not my aim to criticise performers for advancing sometimes bold hypotheses or to separate 'pure historical facts' from contemporary musical mythology.

\section{WHO OR WHAT ADVERTISES MONTEVERDI'S VESPERS I6IO}

The following analysis is based on the assumption that our knowledge of early repertories is shaped not only by the music itself and by the way it is performed, but also (perhaps in particular) by the methods employed to present it. To highlight this point, I now wish to take a look at the front covers of some recordings of the Vespers I6IO. The primary functions of album covers include protecting, advertising and informing, including about genre. ${ }^{9}$ The advertising function serves to encourage and persuade a potential buyer, while the information links the album cover to the

6 Cf. fn. 5. In the context of music recording, it is worth quoting Nick Wilson: 'As Early Music's critics have enjoyed pointing out, there is nothing more inauthentic than recording'; N. Wilson, The Art of Re-enchantment, p. 206.

7 Marcin Napiórkowski, Mitologia wspótczesna [Contemporary mythology], Warszawa 2018, p. I5. Obviously, given the different approaches applied by scholars and the popularity of the term in common parlance, there are plenty of different and sometimes contradictory definitions of 'myth'. For a basic overview, see Robert A. Segal, Myth. A Very Short Introduction, Oxford 2004.

8 A complete list of the analysed recordings can be found in B. Gembicki, Psalmy, mity i memy, pp. $417-445$.

9 M. Torzecki, Oktadki ptyt, pp. 67-87. 
recorded material and helps the listener to classify the album in terms of genre. By means of example, let us consider the cover of a CD album entitled Monteverdi \& Gabrieli. Easter Celebration at St. Marks in Venice I6oo (Brilliant Classics 2018). This cover includes a reproduction of the famous painting by Gentile Bellini showing a procession in St Mark's Square (I496, Venice, Galleria dell'Accademia). Two features of this cover must be noted: Bellini's painting was created about a hundred years before the music recorded on the $\mathrm{CD}$ was composed, and it does not represent an Easter procession. ${ }^{\text {IO }}$ Nonetheless, on the album cover it perfectly fulfils an informative function: it shows the celebration of a festival in St Mark's Square, a festival which took place in the distant past. The use of such telling (and ultimately misleading, from a historical point of view) iconography can be understood in terms of the imperative of visual representation. More than a simple illustration for the music project, it constitutes a kind of confirmation of its authenticity, like a witness from the past. Although the painting does not correspond to the title (and content) of the album on a historical level, it bestows credibility upon the entire music project. The painting of an old master such as Bellini, if only because of its age, becomes evidence,

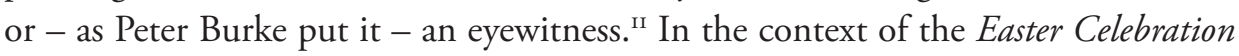
album, a 'witness' in a case in which it never participated.

Keeping in mind the power of iconography in negotiating the contents of albums, let us now turn our gaze to the covers of Vespers music. Of all the albums analysed (including other composers besides Monteverdi), just a few present the performers (mostly the conductor). ${ }^{12}$ A beloved iconographic choice for the Vespers I6Io is instead Marian iconography. Record labels avail themselves of representations of various stages in Mary's life, linked to her feast days: Annunciation, Christmas, Coronation, etc. This in itself shows an interesting tendency: grieving themes, such as the Passion or the Dormition, are consistently avoided.

As with the Easter Celebration album discussed above, most examples from the group of 'Marian' covers employ images produced long before Monteverdi, deliberately or otherwise 'ageing' his Vespers. For instance, as many as four album covers use Simone Martini and Lippo Memmi's Annunciation (ca. 1333) from the Uffizi Gallery in Florence (see Fig. I). ${ }^{\mathrm{I} 3} \mathrm{~A}$ considerable proportion of covers reproduce paintings by

It is also not a Corpus Christi procession, as some scholars claim, e.g. Iain Fenlon, 'Venice. Theatre of the World', in: The Renaissance. From the I470s to the End of the I6th Century, ed. Iain Fenlon, London 1989, p. II6. For the iconographic programme of the Bellini painting, see Elizabeth Rodini, 'Describing Narrative in Gentile Bellini's Procession in Piazza San Marco', Art History 2I (1998) no. I, pp. 26-28.

II Peter Burke, Eyewitnessing. The Uses of Images as Historical Evidence, Ithaca 200I, pp. I3-I4.

I2 See, for example, Claudio Monteverdi. Vespers, Marco Mencoboni, Pan Classics 20I7; Monteverdi. Ad Vesperum Assumptionis Sanctae Mariae Virginis, Marco Gemmani, Amadeus 20I7. On just a few covers, Monteverdi's works are advertised by the composer himself.

I3 Claudio Monteverdi, Vespro della Beata Vergine, Ireneu Segarra, deutsche harmonia mundi 1976; Vespro della Beata Vergine, Jürgen Jürgens, ambitus 1987; Vespers of the Blessed Virgin, The Scholars Baroque Ensemble, Naxos 1993; Vespro della Beata Vergine, Rinaldo Alessandrini, Naïve 2004. 


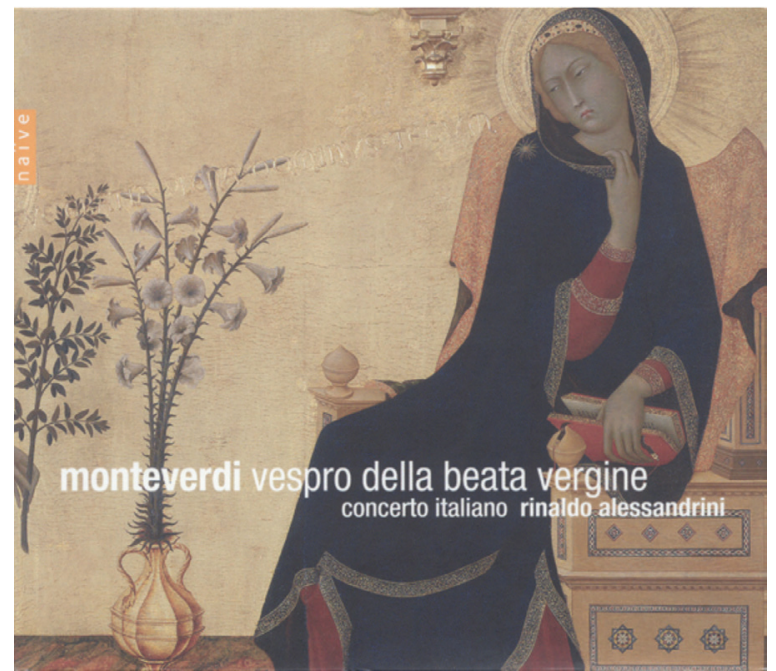

Fig. I. Front cover of the album Vespro della Beata Vergine, Rinaldo Alessandrini, Naïve 2004, showing Simone Martini and Lippo Memmi’s Annunciation from the Uffizi Gallery in Florence, (C) 2002, Photo Scala, Florence

Venetian masters of the Quattro- and Cinquecento, like Titian, Carpaccio, Cima de Conegliano and Giovanni Bellini. ${ }^{14}$ Relatively few albums, meanwhile, present an iconography based on the work of painters contemporary to Monteverdi.

Another iconographic group resorts to motifs that we can label as 'Venetian'. Some of these were probably influenced by Gardiner, although the most popular Venetian motif (the church of St Mark) was first used in the context of the Vespers I6ro earlier. ${ }^{15}$ Within this group, we find covers featuring St Mark's Square, mosaics and domes. ${ }^{16}$ The situation is similar with regard to posters advertising concert performances of the Vespers, where we even find gondolas and Venetian masks. ${ }^{17}$

I4 For instance, Titian's Assunta from the Venetian church of Santa Maria Gloriosa dei Frari can be seen on the cover of Claudio Monteverdi. Vespro della beata Vergine, Jameson Marvin, Titanic I983; Claudio Monteverdi. Vespro della beata Vergine, Philippe Herreweghe, Harmonia Mundi 2006; Monteverdi. Vespers I6Io, John Butt, Linn 2017.

I5 Monteverdi. Vespers of 1610 , Robert Craft, CBS 1967.

I6 See, for example, Claudio Monteverdi. Vespro della Beata Vergine, John E. Gardiner, Decca I975; Monteverdi. Vespers of I6I0, Martin Pearlman, Telarc I997; Claudio Monteverdi. Vespro della Beata Vergine, Nigel Rogers, Azzurra Music 2000; Monteverdi. Vespers of I6ro, Ralph Alwood, Signum Classics 2007.

I7 See, for example, bills of the following concerts: Claudio Monteverdi. Vespers of I6ro, City of Bristol Choir, His Majesty's Sagbutts and Cornetts, D. Ogden, I8 June 20II, Clifton Cathedral, Bristol; Monteverdi. Vespers of I6Io, soloists and Orchestra d'Amici, J. Dunford, 6 April 20I9, Ripon Cathedral; Claudio Monteverdi. Marien-Vesper, Chor St. Martin, Schola Cantorum Gallensis, Capella San Marco, F. Kirk, I September 20I9. On the poster advertising a performance of the Vespers I6ro by the Japanese groups Fons Floris and Contraponto at Tokyo Cathedral on 22 June 20I5, we see a picture of performers 'pasted' onto a photograph of the St Mark interior by means of photomontage. 


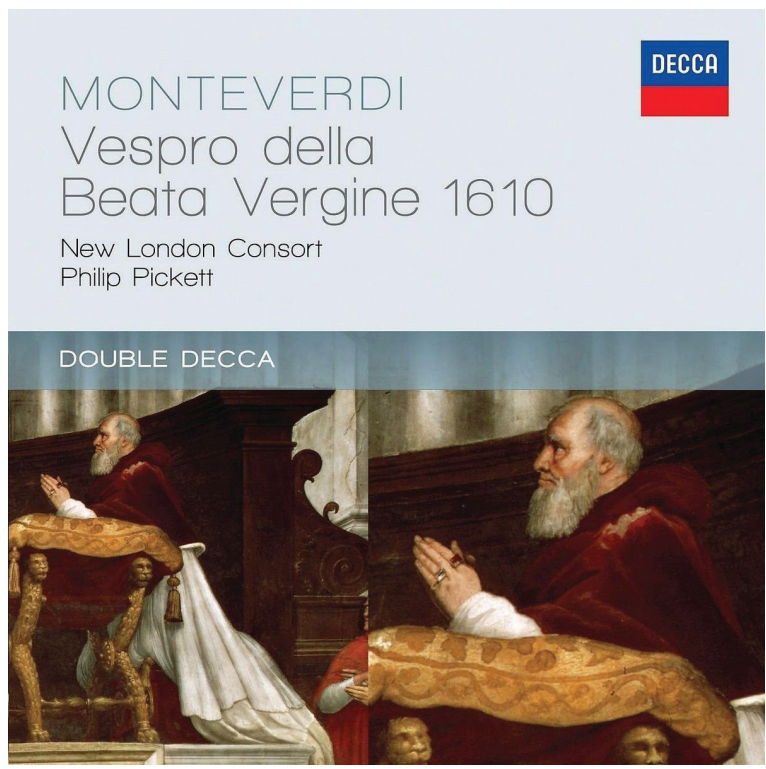

Fig. 2. Front cover of the album Monteverdi. Vespro della Beata Vergine r6ro, Philip Pickett, Decca 2012, showing the kneeling Pope Paul V from Raphael's Room of Heliodorus (Rome, Vatican Palace), photo: The Bridgeman Art Library

One cover features a painting by James Muller (I839, Bury Art Museum) showing the Venetian church of Santa Maria della Salute (only completed in I68I), although in the sleeve notes we read that the musicians, when choosing the forces, took into consideration the fact that the Vespers could have been performed for the first time in the Basilica of Sant'Andrea in Mantua. ${ }^{18}$

It is interesting that on record covers of Monteverdi's Vespers I6ro, Mantuan motifs are conspicuously absent (even if some albums were recorded in Mantua ${ }^{19}$ ). Even the Madonnas by Rubens do not feature, although the painter was active in Mantua at roughly the same time as Monteverdi. The only 'Mantuan' cover I am aware of accompanies the Vespers recorded by Andrew Parrott, and displays Rubens's painting depicting the Holy Trinity adored by the Gonzaga family (1604-1605, Palazzo Ducale, Mantua). ${ }^{20}$ All in all, cover designers more often refer to the composer's Venetian future than to his Mantuan present. The established wisdom seems to be that

I8 Claudio Monteverdi. Vespers of I6ro, Jeannette Sorrell, Avie 2010.

I9 Claudio Monteverdi. Vespro della Beata Vergine I6ıo, Jordi Savall, Astrée Auvidis I989; Claudio Monteverdi. Vespers, Marco Mencoboni, Pan Classics 2017.

20 Claudio Monteverdi, Vespro della Beata Vergine, Andrew Parrott, EMI 1984. This painting was previously used for a recording of Mantuan sacred music (not including Monteverdi): Musiche della Basilica dei Gonzaga di S. Barbara in Mantova, Lino Leali, Ares 1980. 
Monteverdi's Vespers are a forward-looking composition, as Gardiner maintains. ${ }^{2 \mathrm{I}}$ We also find no Roman motifs or motifs connected to Pope Paul V, to whom the print containing the Vespers I6IO was dedicated. In his 'stead', we have the kneeling Julius II from Raphael's Room of Heliodorus (see Fig. 2), which may represent a distant allusion to 'Palestrinian iconography' (Palestrina's first book of masses famously depicts the composer kneeling in front of Pope Julius III). ${ }^{22}$ Yet the reason for using this portrait in the context of Monteverdi's Vespers is not quite clear. Moreover, as Gardiner notes, Monteverdi ultimately failed to receive a post in Rome, and his print (including the motet Nigra sum which Gardiner regards as 'inappropriate' for Roman circles) could not have been well received there - unlike in Venice, of course... In this narrative, the 'musical modernity' of Monteverdi's Vespers reinforces the connection to Venice, the most 'modern' musical centre of seventeenth-century Italy.

\section{OTHER VESPERS BY MONTEVERDI AND HIS FELLOW COMPOSERS}

The Vespers I6Io represent the sole example in the extant oeuvre of Monteverdi where all the compositions contained in a collection form a single (although, from a liturgical point of view, perhaps not entirely cohesive) Vespers service dedicated to a specific saint. We know from some accounts contemporaneous to Monteverdi about a number of Vespers services during which he led the cappella (and probably presented his own compositions). ${ }^{23}$ Moreover, there are some settings of Vesper psalms and the Magnificat by Monteverdi which survive in his prints from I64I and I650, although they are not ordered in a particular Vespers service as the compositions in the I6ro print. The source-documented practice of selecting psalms, antiphons, etc. for the needs of particular services has encouraged musicians to produce new arrangements of Vespers cycles for various occasions. ${ }^{24}$

Present-day musicians define such work frequently with the capacious and authoritative term 'reconstruction' (Gardiner uses the rather enigmatic 're-creation'). I do not set out to criticise procedures of that type or to scrupulously verify the

2I John Whenham, Monteverdi. Vespers (I6I0), Cambridge 1997, p. 38.

22 Jane A. Bernstein, 'Publish or Perish? Palestrina and Print Culture in I6th-Century Italy', Early Music 35 (2007) no. 2, pp. 226-227.

23 Frits Noske, 'An unknown work by Monteverdi: The Vespers of St. John the Baptist', Music \& Letters 66 (I985) no. 2, p. II9; Jeffrey Kurtzman, 'Monteverdi's Missing Sacred Music. Evidence and Conjectures', in:The Musicologist and Source Documentary Evidence. A Book of Essays in Honour of Professor Piotr Poźniak on His 7oth Birthday, eds. Zofia Fabiańska, Andrzej Sitarz, Piotr Wilk and Jakub Kubieniec, Kraków 2009, pp. I88-190, I95. See also a newly published volume, Monteverdi a San Marco. Venezia I6I3-I643, eds. Rodolfo Baroncini and Marco di Pasquale, Lucca 2020. Unfortunately, I was unable to consult this volume before submitting the present article.

24 Stephen Bonta, 'The Use of Instruments in Sacred Music in Italy 1560-1700', Early Music I8 (1990) no. 4, p. 522; Stephen Bonta, 'Liturgical Problems in Monteverdi's Marian Vespers', Journal of the American Musicological Society 20 (1967) no. I, pp. 93-106. 
source context, although it should be pointed out that reconstructors rarely address in liner notes the degree of verisimilitude of the compilations they present. With regard to the reception of such reconstructions, another issue that needs to be mentioned is that not all listeners have the opportunity to consult the liner notes of an album, where some procedures applied by the reconstructors can be revealed. This refers particularly to the users of streaming platforms, who usually can access only the track list and the album's front cover. ${ }^{25}$

In the discourse staged through phonography, Vespers are not only re-created or reconstructed, but even 'discovered', as we learn from the description of one of the recordings of Vespers music by Monteverdi conceived by Denis Stevens (Christmas Vespers, see Table I). What was needed to make this 'discovery' possible was liturgical and musicological knowledge allowing dispersed compositions to be merged and repaired (according to Stevens). On the back cover of the recording, there is a short description entitled 'The discovery of Monteverdi's Christmas Vespers by Professor Denis Stevens', where we read that 'the composer's intentions have been honoured, the errors of his publisher corrected, and the Christmas Vespers restored to their rightful place in the Monteverdian repertory'.

It should be noted that the majority of recordings analysed contain not only psalms and the Magnificat, but also other items deemed necessary to attain a plausible recreation of the sound of a liturgical celebration. In the case of the Vespers i6ro, Monteverdi's music is often accompanied by plainsong Marian antiphons, the anonymity of which supposedly does not disturb our understanding of the concept of authorship in relation to these works. ${ }^{26}$ In fact, quite rarely do musicians use pieces by other composers: this state of things can be interpreted as the desire to respect the supposed 'integrity' of the repertoire contained in the print of I6Io. However, on some recordings, musicians change the original order of the pieces and reject one of the two settings of the Magnificat, nearly always the 'more modest' (for six parts). This recombination of elements makes virtually each successive recording essentially 'different'. In the case of recordings of 'other Vespers by Monteverdi' or by other composers, musicians frequently confine themselves to psalms and the Magnificat, with perhaps plainsong antiphons, or else they look for motets, hymns and instrumental works from other sets by the particular composer. It is important to note that Vespers albums thus constructed are nearly always attributed to the composer who wrote the psalms, even if the duration of the other compositions lengthens them considerably (see Table I).

25 On changes in listening technology, see Martin Scherzinger, 'Toward a History of Digital Music. New Technologies, Business Practices and Intellectual Property Regimes', in: The Cambridge Companion to Music in Digital Culture, eds. Nicholas Cook, Monique M. Ingalls and David Trippett, Cambridge, 2019, pp. 33-57.

26 On the delicate matter of the modern (and often anachronistic) understanding of the ontology of early music works and their authorship, see, for instance, J. Butt, Playing with History, pp. 53-95; N. Wilson, The Art of Re-enchantment, pp. 40-42. 
Thanks to the reconstruction practice just discussed, we can find in record shops (or on streaming platforms) Monteverdi Vespers for the feast days of St John the Baptist, confessors, martyrs, Christmas, Archangel Gabriel, St Joseph, Ascension Day and St Barbara, as well as other 'Marian Vespers'. The relationship between some of these recordings and the Vespers I6IO is expressed very often in booklets or on covers: we learn that some 'Monteverdi Vespers' are by no means 'inferior' to those from I6IO, passing over the question of the extent to which they are in fact by Monteverdi. ${ }^{27}$ The appearance of 'new' Marian Vespers by Monteverdi, often notated with dates, could cause quite some confusion for the listener. When seeing a disc entitled Vespro della Beata Vergine, we can no longer be sure which Vespers we are dealing with. ${ }^{28}$

Table I. Recordings of 'other' Vespers by Monteverdi.

\begin{tabular}{|l|l|l|l|l|}
\hline $\begin{array}{l}\text { Title of the } \\
\text { compilation }\end{array}$ & $\begin{array}{l}\text { Sources of } \\
\text { Monteverdi's } \\
\text { music }{ }^{29}\end{array}$ & $\begin{array}{l}\text { Other composers on } \\
\text { the album }\end{array}$ & $\begin{array}{l}\text { Conductor / } \\
\text { music director }\end{array}$ & $\begin{array}{l}\text { Label and year of } \\
\text { release }\end{array}$ \\
\hline $\begin{array}{l}\text { Second Vespers } \\
\text { for the Feast of } \\
\text { Santa Barbara }\end{array}$ & I610 & $\begin{array}{l}\text { G. Amigone; } \\
\text { Anon. (chant); } \\
\text { P. Nicholson (organ } \\
\text { improvisation); } \\
\text { G.P. da Palestrina }\end{array}$ & H. Christophers & Hyperion I988 \\
\hline $\begin{array}{l}\text { Vespri solenni } \\
\text { per la festa di } \\
\text { San Marco }\end{array}$ & $\begin{array}{l}\text { I610 } \\
\text { I620 }\end{array}$ & $\begin{array}{l}\text { Anon. (chant); } \\
\text { G. B. Buonamente; } \\
\text { G. Gabrieli; F. Usper }\end{array}$ & R. Alessandrini & Nä̈ve 20I4 \\
\hline $\begin{array}{l}\text { Vespri di S. } \\
\text { Giovanni } \\
\text { Battista }\end{array}$ & I64I & $\begin{array}{l}\text { Anon. (chant); } \\
\text { N. Bazzino; } \\
\text { D. Castello; G. Gabrieli; } \\
\text { A. Grandi }\end{array}$ & G. Leonhardt & Philips I988 \\
\hline
\end{tabular}

27 See description on the back cover of Eternal Monteverdi, Vespro della Beata Vergine I65o, Roland Wilson, deutsche harmonia mundi 20I7, where we read: 'His "other Marian Vespers", taken from this publication [the I650s print] is very different to the famous I6ro Vespers but in no way inferior and really deserves equal fame'. On most of the albums analysed here, the titles come from contemporary musicians or musicologists: all of them in the case of 'other Monteverdi Vespers' and the clear majority in the case of Vespers by other composers.

28 For example: Monteverdi. Vespers of the Blessed Virgin, Jonathan Ofir, CN 2013.

$29 \mathbf{1 6 0 9}$ = C. Monteverdi, L'orfeo. Favola in musica..., Venice I609; I6ro = C. Monteverdi, Sanctisssimae Virginis missa senis vocibus ac vesperae..., Venice I610; 1618/1627 = G.B. Ala, Primo libro di concerti ecclesiastici..., Milano I6I8 (preserved incompletely, see fn. 30); 1620 = G.C. Monteverdi, Delli af fetti musici..., Venice 1620; 1624 = L. Calvi, Seconda raccolta de sacri canti..., Venice 1624; $1625 / \mathbf{I}=$ L. Simonetti, Ghirlanda sacra..., Venice I625; 1625/2 = F. Sammaruco, Sacri affetti..., Rome I625; I641 = C. Monteverdi, Selva morale e spirituale, Venice 1640-4I; I650 = C. Monteverdi, Messa a 4 voci et salmi..., Venice I650; I65I = Raccolta di motetti di Gasparo Casati..., Venice I65I; I660? = Salve Regine del Sig. Claudio Monteuerde, [Venice] between 1662-67? (dating after Printed Sacred Music Database, http://www.printed-sacred-music.org, accessed to November 2020). 


\begin{tabular}{|c|c|c|c|c|}
\hline $\begin{array}{l}\text { Vespro della } \\
\text { Festa di San } \\
\text { Giovanni } \\
\text { Battista }\end{array}$ & $\begin{array}{l}164 \mathrm{I} \\
1650\end{array}$ & D. Castello & P. Vorverk & $\begin{array}{l}\text { Cantilena } \\
\text { Records I999 }\end{array}$ \\
\hline $\begin{array}{l}\text { Vesperae in } \\
\text { Nativitate } \\
\text { Sti. Joannis } \\
\text { Baptistae }\end{array}$ & $\begin{array}{l}1618 / 1627^{30} \\
1620 \\
1625 / 1 \\
1641 \\
1650\end{array}$ & $\begin{array}{l}\text { N. Bazzini; } \\
\text { H. Bildstein; } \\
\text { C. Erbach; L.; H.L. } \\
\text { Haßler; L. Viadana }\end{array}$ & F. Raml & MDG Scene 1995 \\
\hline $\begin{array}{l}\text { Les vêpres } \\
\text { solennelles à St } \\
\text { Jean-Baptiste }\end{array}$ & $\begin{array}{l}\mathrm{I} 64 \mathrm{I} \\
\mathrm{I} 650\end{array}$ & M. Neri; G. Rovetta & F. Lasserre & $\begin{array}{l}\text { Zig-Zag } \\
\text { Territoires } 2007 \\
(2003)^{31}\end{array}$ \\
\hline $\begin{array}{l}\text { Vespro di San } \\
\text { Giuseppe }\end{array}$ & I64I & - & C. Cavina & Glossa $2008^{32}$ \\
\hline $\begin{array}{l}\text { Vespro solenne } \\
\text { di San Lorenzo }\end{array}$ & $\begin{array}{l}1610 \\
1625 / \mathrm{I} \\
164 \mathrm{I} \\
165 \mathrm{I}\end{array}$ & $\begin{array}{l}\text { G.B. Buonamente; } \\
\text { F. Cavalli }\end{array}$ & D. Fasolis & $\begin{array}{l}\text { The Classic Voice } \\
\text { 200I }\end{array}$ \\
\hline $\begin{array}{l}\text { Vespro di } \\
\text { San Gabriele } \\
\text { Arcangelo }\end{array}$ & I64I & - & C. Cavina & Glossa $2008^{33}$ \\
\hline $\begin{array}{l}\text { Ad Vesperas } \\
\text { Beatae Maria } \\
\text { Virginis. } \\
\text { Monteverdi. } \\
\text { Grandi }\end{array}$ & $\begin{array}{l}1610 \\
1625 / \mathrm{I} \\
164 \mathrm{I} \\
1650\end{array}$ & $\begin{array}{l}\text { Anon.; P. Despont } \\
\text { (organ improv.); } \\
\text { A. Grandi }\end{array}$ & L. Gendre & Cascavelle 2003 \\
\hline $\begin{array}{l}\text { Eternal } \\
\text { Monteverdi. } \\
\text { Vespro Della } \\
\text { Beata Vergine } \\
\text { I650 }\end{array}$ & $\begin{array}{l}1625 / \mathrm{I} \\
164 \mathrm{I} \\
1650 \\
1660 ?\end{array}$ & $\begin{array}{l}\text { A. Grandi; M. Neri; } \\
\text { A. Rigatti }\end{array}$ & R. Wilson & $\begin{array}{l}\text { Deustche } \\
\text { harmonia mundi } \\
2017\end{array}$ \\
\hline $\begin{array}{l}\text { Vespro per la } \\
\text { Salute. I650 }\end{array}$ & $\begin{array}{l}\mathrm{I} 6 \mathrm{I} 8 / \mathrm{I} 627 \\
\mathrm{I} 624 \\
\mathrm{I} 625 / 2 \\
\mathrm{I} 64 \mathrm{I} \\
\mathrm{I} 650\end{array}$ & $\begin{array}{l}\text { G. De Buono; } \\
\text { F. Cavalli; } \\
\text { M. A. Ferro; } \\
\text { A. Grandi; T. Merula; } \\
\text { C. Monteverdi; } \\
\text { G. Picchi; G. Scarani; } \\
\text { M. Uccellini }\end{array}$ & F. Lassarre & $\begin{array}{l}\text { Pierre Verany } \\
\text { I997 }\end{array}$ \\
\hline
\end{tabular}

30 Mentioned on some recordings as the source for the Sancta Maria, succurre miseris is the later reprint of this piece which appeared in Johann Donfrid, Promptuarii Musici..., Strasbourg 1627.

3I Originally issued as disc I in: Monteverdi: Selva Morale \& Spirituale, Françoise Lasserre, Zig-Zag Territoires 2003, reissued in 2007 as a separate album.

32 Issued as disc 2 in: Claudio Monteverdi, Selva morale e spirituale, Claudio Cavina, Glossa 2008.

33 Issued as disc I in: ibid. 


\begin{tabular}{|c|c|c|c|c|}
\hline $\begin{array}{l}\text { Ad Vesperum } \\
\text { Assumptionis } \\
\text { Sanctae Mariae } \\
\text { Virginis }\end{array}$ & $\begin{array}{l}\mathrm{I} 618 / \mathrm{I} 627 \\
\mathrm{I} 624 \\
\mathrm{I} 625 / \mathrm{I} \\
\mathrm{I} 625 / 2 \\
\mathrm{I} 64 \mathrm{I} \\
\mathrm{I} 650\end{array}$ & Anon. (chant) & M. Gemmani & Amadeus 2017 \\
\hline $\begin{array}{l}\text { Vesperae de } \\
\text { Confessore - } \\
\text { choral works }\end{array}$ & $\begin{array}{l}\mathrm{I} 64 \mathrm{I} \\
\mathrm{I} 650\end{array}$ & Anon. (chant) & R. Gini & Dynamic 2007 \\
\hline $\begin{array}{l}\text { Vêpres d'un } \\
\text { confesseur }\end{array}$ & $\begin{array}{l}164 \mathrm{I} \\
1650 \\
\end{array}$ & - & F. Lassere & $\begin{array}{l}\text { Zig Zag } \\
\text { Territoires } 2003^{34}\end{array}$ \\
\hline $\begin{array}{l}\text { Vêpres à des } \\
\text { Saints Martyres }\end{array}$ & $\begin{array}{l}\text { I6IO } \\
\text { I64I }\end{array}$ & - & F. Lassere & $\begin{array}{l}\text { Zig Zag } \\
\text { Territoires 20035 }\end{array}$ \\
\hline $\begin{array}{l}\text { Christmas } \\
\text { Vespers }\end{array}$ & $\begin{array}{l}\mathrm{I} 64 \mathrm{I} \\
\mathrm{I} 650\end{array}$ & - & K.G. Nanfred & CLASSICO: 1999 \\
\hline $\begin{array}{l}\text { Christmas } \\
\text { Vespers }\end{array}$ & $\begin{array}{l}164 \mathrm{I} \\
\mathrm{I} 650\end{array}$ & Anon. (chant) & D. Stevens & $\begin{array}{l}\text { Midland Bank } \\
\text { I979 }\end{array}$ \\
\hline $\begin{array}{l}\text { Christmas } \\
\text { Vespers }\end{array}$ & $\begin{array}{l}1610 \\
1641 \\
1650\end{array}$ & Anon. (chant) & R. Paczian & $\begin{array}{l}\text { Bach Musica } \\
\text { New Zealand } \\
2010\end{array}$ \\
\hline $\begin{array}{l}\text { Vesperae in } \\
\text { Nativitate } \\
\text { Domini }\end{array}$ & $\begin{array}{l}164 \mathrm{I} \\
1650\end{array}$ & $\begin{array}{l}\text { C.M. Cozzolani; } \\
\text { G. Gabrieli }\end{array}$ & E.V. Nevel & Eufoda 2003 \\
\hline $\begin{array}{l}\text { Vespera in } \\
\text { Natale I633 }\end{array}$ & $\begin{array}{l}1609 \\
164 \mathrm{I}\end{array}$ & $\begin{array}{l}\text { G. Bassano; } \\
\text { A. Gabrieli, G. Gabrieli, } \\
\text { A. Grandi }\end{array}$ & C. Kabits & $\begin{array}{l}\text { Cäcilienchor } \\
\text { 2017? }\end{array}$ \\
\hline $\begin{array}{l}\text { Vesper zum } \\
\text { Fest Christi } \\
\text { Himmelfahrt }\end{array}$ & $\begin{array}{l}\text { I64I } \\
1650\end{array}$ & - & H. Arman & Capriccio 1995 \\
\hline $\begin{array}{l}\text { The Other } \\
\text { Vespers }\end{array}$ & $\begin{array}{l}\mathrm{I} 624 \\
\mathrm{I} 64 \mathrm{I}\end{array}$ & $\begin{array}{l}\text { G. Gabrieli; } \\
\text { D. Castello; I. Donati; } \\
\text { G. Frescobaldi; } \\
\text { G. P. Da Palestrina / } \\
\text { G. B. Bovicelli; } \\
\text { F. Usper; L. Viadana; }\end{array}$ & R. Hollingworth & Decca 2017 \\
\hline $\begin{array}{l}\text { Ceremonial } \\
\text { Vespers in St } \\
\text { Mark's }\end{array}$ & $\begin{array}{l}\mathrm{I} 64 \mathrm{I} \\
\mathrm{I} 650\end{array}$ & Anon. (chant) & D. Stevens & Schwann $198 \mathrm{I}^{36}$ \\
\hline $\begin{array}{l}\text { Monteverdi. } \\
\text { Abendmusik. } \\
\text { Vespers in San } \\
\text { Marco }\end{array}$ & $\begin{array}{l}164 \mathrm{I} \\
\mathrm{I} 650\end{array}$ & - & F. Bernius & FSM 1983 \\
\hline
\end{tabular}

34 Issued as disc 3 in: Claudio Monteverdi: Selva Morale \& Spirituale, Françoise Lasserre, Zig-Zag Territoires 2003.

35 Issued as disc 2 in: ibid.

36 This is a reissue of the album Christmas Vespers, Denis Stevens, Midland Bank 1979. 
It is worth noting that the reconstructions analysed here are almost never re-recorded. By way of example, no one has made a new recording of Monteverdi's Vespers for St Barbara. Similarly, musicians rarely use the material of the Vespers I6ro in their reconstructions, except in some cases where only one piece from the print is used (mainly Deus in adjutorium - Monteverdi's only setting of this text - or one of two settings of the Magnificat), although the practice they continuously invoke perhaps ought to induce them to do so..$^{37}$ This suggests that the Vespers I6IO are perceived - to a certain extent - as a cohesive 'work' which is not to be dismembered, not even in order to produce new 'historically informed' reconstructions.

Now I would like to turn for a moment to Vespers by other Italian composers, sometimes described in booklets as 'no worse than Monteverdi's..$^{38}$ Some of these recordings not so much refer to Monteverdi's Vespers I6IO as actually rival them. ${ }^{39}$ Graham Dixon's reconstruction of Monteverdi's Second Vespers for the Feast of Santa Barbara (see the first record in Table I ${ }^{40}$ may have encouraged musicians to construct other Vespers for the Chapel of St Barbara in Mantua, this time by Amante Franzoni, making use of extant works by that composer in other sources. ${ }^{4 \mathrm{I}}$ Yet the service opens with Deus in adjutorium from Monteverdi's i6ıo print.

Furthermore, the connotation of an album by referring to the year I6ro is no longer reserved solely for Monteverdi, and no longer is there just a single example of 'I6ro Marian Vespers'. We also have 'I6ro Marian Vespers' by Giovanni Paolo Cima, which no longer comprise psalms, but rather motets and a Magnificat setting from his Concerti Ecclesiastici (Milan I6IO) and other sources (see Fig. 3). ${ }^{42}$ Close to that date, we also have 'I6r2 Italian Vespers' reconstructing Vespers for the Feast of Our Lady of the Rosary and at the same time the anniversary of the Battle of Lepanto. ${ }^{43}$ Dates appear on many other recordings as well. They may be linked to other issues, which often cannot be interpreted on the basis of the cover alone. Some of them probably create deliberate intertextual reference to Monteverdi's Vespers of I6IO.

37 For more details, see B. Gembicki, Psalmy, mity i memy, pp. I80-198.

38 See, for example, the back cover of the album: Giovanni Paolo Cima. Vespro della Beata Vergine, Daniela Dolci, PAN CLASSICS 2015.

39 The title of one album by I Faggiolini does this in a direct and humorous way: Monteverdi. The Other Vespers, Robert Hollingworth, Decca 2017.

40 Graham Dixon, 'Monteverdi’s Vespers of ı6ıо: “della Beata Vergine”?', Early Music I5 (1987) no. 3, pp. 386-390.

4I Amante Franzoni. Vespro per la Festa di Santa Barbara, Francesco Moi, Brilliant 2016.

42 The front cover design is based on the painting The Virgin in Prayer by Sassoferrato (1640/50, National Gallery, London), as in the case of Monteverdi's Vespers I6I0, John E. Gardiner, Decca I995. Yet this painting and this type of iconographical representation of Mary are quite common with sacred music recordings.

43 Italian Vespers I6I2, Robert Hollingworth, Decca 2012. 


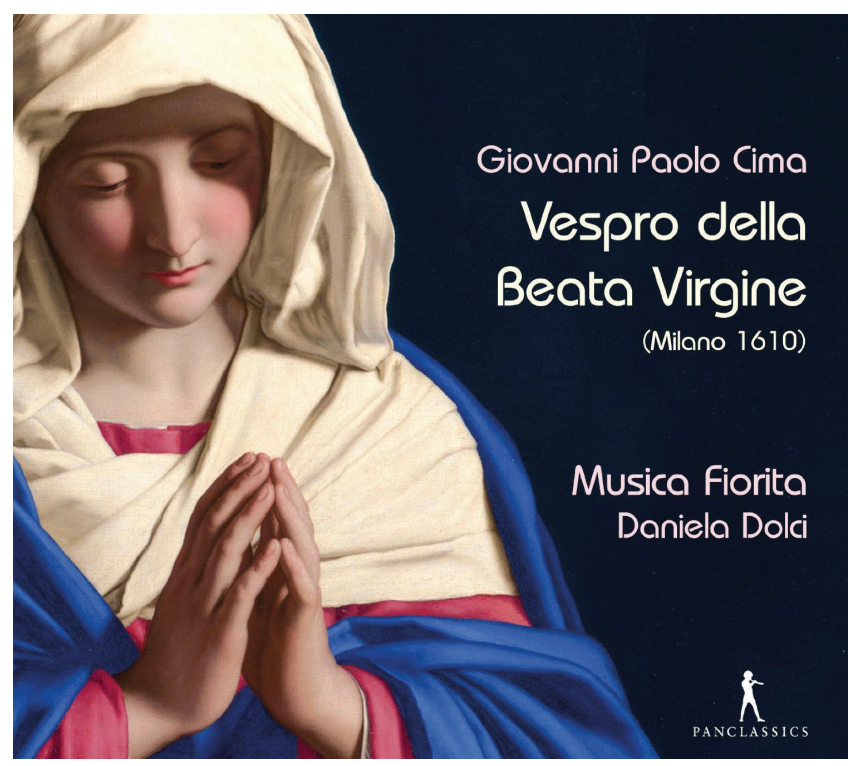

Fig. 3. Front cover of the album Giovanni Paolo Cima. Vespro della Beata Virgine, Daniela Dolci, PAN CLASSICS 2015, cover picture: Sassoferrato The Virgin in Prayer (1640/50, National Gallery, London)

Via such a link to Monteverdi's Vespers of I6IO - which, as we have seen, are often 'Veniceised' - Vespers music in general is often presented through iconographies that evoke both Venice and St Mark's. In fact, looking at some record covers and concert posters, one may gain the impression that Vespers were a particular speciality of Venetian composers working at St Mark's. Among the records and concerts, one finds programmes entitled 'Venetian Vespers'. Three albums, apart from sharing such a title, benefit (coincidentally?) from the same iconographical source for their cover design: a painting by seventeenth-century artist Joseph Heintz the Younger showing St Mark's Square in Venice during carnival time (Rome, Galleria Doria-Pamphili, see Fig. 4). ${ }^{44}$ It is interesting to note that there are far fewer compilations referring to other cities, and those that exist do not use an adjective from the name of the city (the only exception being a single recording of 'Roman Vespers', including music by George Frideric Handel).45

In the context of 'Venetian Vespers' hypothetically related to St Mark's, the credibility of the hypothesis may be strengthened by employing not only pictures showing the church but also photos of performers situated inside the church. Among the relatively numerous productions of Vespers related to St Mark's, only a few have been recorded

44 Monteverdi, Rigatti, Grandi, Cavalli. Venetian Vespers, Paul McCreesh, Archiv Produktion I993; Antonio Rigatti. Venetian Vespers of I640, James Fankhauser, Skylark I999; Cavalli, Monteverdi, Vêpres Vénitiennes, Harmonia Mundi 2002 (a compilation of two recordings issued separately).

45 Handel. Roman Vespers, Michael Korn, RCA 1986. 


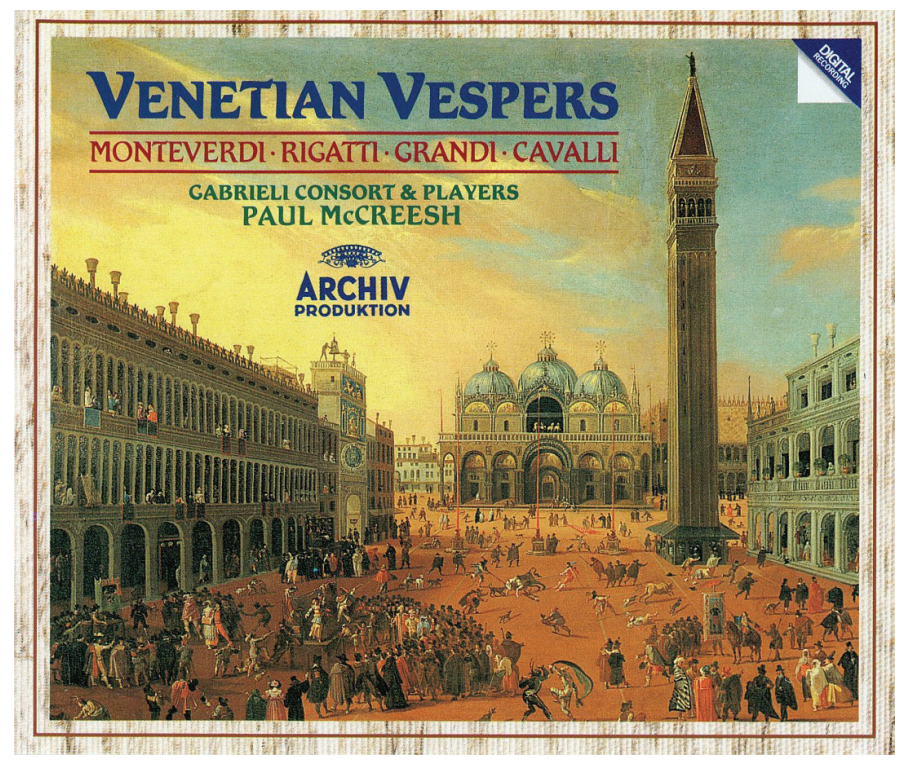

Fig. 4. Front cover of the album Monteverdi, Rigatti, Grandi, Cavalli. Venetian Vespers, Paul McCreesh, Archiv Produktion 1993, based on a painting by Joseph Heintz the Younger showing St Mark's Square in Venice during carnival time (I648/49, Rome, Galleria Doria-Pamphili), photo: Jürgen Liepe

at this venue - including albums by Gardiner and Marco Gemmani (Amadeus 2017). Rinaldo Alessandrini's production entitled Monteverdi. Vespro per San Marco (Naïve 20I4) - despite such plans - was ultimately not recorded there. The recording took place in the church of St. Barbara in Mantua - another 'authentic' venue associated with Monteverdi, but not with the reconstruction presented in the recording. ${ }^{46}$ The album Monteverdi in San Marco (Arcana 2017) by Odhecaton was also not recorded in the church it refers to. Nevertheless, the booklet contains pictures of the musicians standing in front of the chancel at St Mark's during a concert.

The phenomenon of 'Venetian Vespers' linked to St Mark's may be interpreted as a form of sanmarcocentrismo, which emphasises the disproportioned attention that modern scholars devote to Venice's patron church, overlooking other important local institutions. ${ }^{47}$ Most of the compilations of sacred music (not only for Vespers) by Venetian composers refer to their possible performance at St Mark's, even though,

46 This information appears in the short introductory text by Alessandrini in the booklet attached to the album, entitled 'Monteverdi in Venice' (pp. I6-2I). According to the author, the Church of St Barbara is a 'natural substitute' for the Venetian temple: 'The decision to make the present recording in the palatine basilica of Santa Barbara in Mantua offered the "natural" substitute for St Mark's, which for obvious reasons was not available to us', p. I8.

47 Elena Quaranta, Oltre San Marco. Organizzazione e prassi della musica nelle chiese di Venezia nel Rinascimento, Firenze 1998. 
as numerous studies have shown, we can almost never be certain that their compositions were linked to that particular church. ${ }^{48}$ Suffice it to mention Andrew Parrott's recording from 1989 containing a reconstruction of the solemn thanksgiving mass which took place at St Mark's in I63I at the end of the plague. This album, which draws music largely from Monteverdi's Selva Morale, has received robust criticism for the historically inappropriate selection of pieces in connection with the reconstructed event. ${ }^{49}$ It is rather amusing to note that there is, in fact, Vespers music strongly linked to the practice at St Mark's, but it is rarely recorded. ${ }^{50} \mathrm{I}$ am thinking of the so-called salmi brevi for two choirs, composed and performed at St Mark's. Evidently, salmi brevi are regarded as not as attractive as the more ambitious concertato psalm settings by Monteverdi, suggesting that in this case aesthetic evaluation overrides historical evidence. Among the analysed albums, I did not find a single recording of Vespers for the most important feast of the Roman Catholic Church: Easter. Within the context of the rite of St Mark's in Venice, such an arrangement might prove particularly interesting, given the numerous oddities deriving from the local rite used in that church. ${ }^{\mathrm{I}}$ Of all the recordings analysed here, not including Christmas feast days of a strongly Marian tinge, just a single album is dedicated to Christ - the central figure in most liturgical practice (at least in theory). ${ }^{52}$ Extant breviaries and the huge number of still unrecorded Vespers works allow for what is practically an infinite number of new 'reconstructions'. Against this background, it seems that the huge popularity of Monteverdi's Vespers I6Io has accustomed listeners and musicians to think of Vespers as a Marian service. ${ }^{33}$ Indeed, the vast majority of Vespers reconstructions in my sample are linked to Marian feast days. In some instances, when the sequence of psalms on the disc does not correspond to that established for Marian feast days (Dixit dominus, Laudate pueri, Laetatus sum, Nisi Dominus, Lauda Jerusalem), the figure of Mary nevertheless appears on the cover. ${ }^{54}$

48 Linda M. Koldau, Die venezianische Kirchenmusik von Claudio Monteverdi, Kassel 2005, pp. 78-94, IO5-IIO.

49 Monteverdi. Mass of Thanksgiving. Venice I63I, Andrew Parrott EMI 1989; Jeffrey Kurtzman, 'Monteverdi's Mass of Thanksgiving. Da Capo', in: Fiori musicali: liber amicorum Alexander Silbiger, eds. Claire Fontijn and Susan Parisi, Sterling Heights 20I0, pp. II9-I20.

50 James H. Moore, Vespers at St. Mark's. Music of Alessandro Grandi, Giovanni Rovetta, and Francesco Cavalli, Ann Arbor, Mich. 198I, pp. I7I-209; James H. Moore, "The "Vespero delli Cinque Laudate" and the Role of "Salmi Spezzati" at St. Mark's', Journal of the American Musicological Society 34 (198I) no. 2, pp. 249-278.

5I J.H. Moore, Vespers at St. Mark's, p. I27.

52 Monteverdi. Vesper zum Fest Christi Himmelfahrt, Howard Arman, Capriccio 1996.

53 That problem was already raised in: Helmut Hucke, 'Die fälschlich so genannte "Marien-Vesper" von Claudio Monteverdi', in: Bericht über den internationalen musikwissenschaftlichen Kongress Bayreuth I98I, Kassel 1984, pp. 295-305.

54 See, for example, Fabri. Vesperae a quattour choris a san Luigi dei Francesi, Bernard Fabre-Garus, Naïve 1999. 


\section{WAITING FOR ANOTHER VESPERS BY MONTEVERDI}

In an important contribution on the 'powers of imagination', Marcin Napiórkowski stated that 'people dealing with the past play different games based on different rules. One of the rules of each of them is the belief that we are all playing the same game'.5s Against this background, it would seem impossible to refer to the legacy of historiography, musicological research and phonography as a complementary whole. I have endeavoured to show that 'newly constructed' Vespers often not only fail to fill the gaps in repertoire yet to be recorded, but actually create an unpredictable list of imaginary settings, and also that music albums are vehicles not only of the recorded music but also of knowledge related to it. I mean here not only the information which can be read in the liner notes but also the message - sometimes deliberately hidden, sometimes completely accidental - which emerges from the combination of the text and the graphic design of the front album cover.

On the front covers of some recordings, we find information about the provenance of the works, and also to the effect that we are essentially dealing with a present-day compilation of compositions from specific collections. ${ }^{56}$ (Significantly, it is more often small record labels that display such 'honesty'. The lack of such details might be justified, of course, by design priorities.) On the above-mentioned recording of the hypothetical Monteverdi Vespers for St Barbara's Day, the reverse side of the cover carries information about who produced the 'reconstruction' and a list of tracks which the listener should programme in order to hear only original music by Monteverdi. ${ }^{57}$

The question arises as to how we should define recordings on which certain questions have been passed over. Are we entitled to use the word 'dishonesty', for example, in the case of an album of Francisco Guerrero's Vespers for All Saints' Day, on which two of the five psalms were not composed by him (as we only learn on reading the booklet)? Does the composer's name as given on the cover mean the same as the name of a book's author? The history of record covers is connected to some extent to book cover design..$^{8}$ For instance, album covers of early music recordings issued by Archiv Produktion in the I950s were modelled on the covers of academic books, as noted by Vincenzo Borghetti. ${ }^{59}$ It is hardly surprising that we very often fail to

'Ludzie zajmujący się przeszłością grają w różne gry o różnych zasadach. Jedną z reguł każdej z nich jest wiara w to, że wszyscy gramy w tę samą grę’. Marcin Napiórkowski, Wtadza wyobraźni. Kto wymyśla, co zdarzyto się wczoraj? [The powers of imagination: who dreams up what happened yesterday?], Warsaw 20I4, p. 40

56 Lodovico Viadana. Vespri di San Luca. (dai Salmi a quattro chori, op. XXVII, Venezia I6I2), Romano Vettori, fonè 1995 .

57 See the back cover of the Second Vespers for the Feast of Santa Barbara, Harry Christophers, Hyperion I988.

58 K. Edge, The Art of Selling Songs, p. 9r.

59 V. Borghetti, 'Purezza e trasgressione', p. 59. 
ask ourselves about the link between a composer's name and the title of a work. We do not generally process content of that sort; we usually consider that it does not require our vigilance or verification - unless we are particularly interested in the relevant field or enthusiasts of conspiracy theories. After all, 'what we see exists', so why should it not have existed before? Perhaps everything would change if listeners developed the capacity to perceive a composer's name (only) as part of an album title?

Phonography has undoubtedly enlivened discussion between musicologists and musicians. Performers can achieve 'much more' than scholars, as in the case of the above-mentioned recording of the Vespers for St Barbara, removing a question mark raised by a scholar, who in any case was merely advancing a hypothesis. As a consequence, we find on the recording market more works (or rather titles) by some composers than in the catalogues of their output.

Although their liturgical context is frequently invoked, it is self-evident that Vespers or masses by Monteverdi and other composers have long since functioned outside the liturgy. Even reconstructions on which we hear liturgically adequate antiphons, the ringing of the authentic bell of St Mark's at the beginning of the service ${ }^{60}$ or the firing of cannons between lines of the Magnificat ${ }^{6 \mathrm{I}}$ will not recreate the original cultural context, which will remain beyond our cognitive capacities. This may also confirm the truism that the meaning of a given music work is never finally established. The music industry has 'finally' offered a home for the 'homeless' Vespers I6Io, and it would be difficult to find a more splendid and widely recognisable edifice as St Mark's church in Venice. It is worth noting that sometimes such a connection can be imposed on a particular recording completely 'from outside' (without the intention of musicians or producers). In one of her articles, the architectural historian Deborah Howard analyses recordings linked to the repertoire of St Mark's. As we read at the start of that text: 'This essay reviews a range of commercial recordings of music written for St Mark's in relation to the real acoustic conditions of the basilica'. Howard writes of the above-mentioned recording by Gardiner and, although aware that those compositions were not written with that church in mind, she analyses other recordings of the Vespers I6IO within the context of the 'actual' - as she asserts - acoustic conditions of St Mark's, despite the fact that the artists behind the analysed albums did not state that they were thinking about San Marco when recording the music. ${ }^{62}$

On other occasions when musicians/producers do not share with the listeners any information about the possible original place of performance, it can be considered

60 The ringing of the bell of St Mark's can be heard at the beginning of Lo sposalizio. Music by Giovanni $\&$ Andrea Gabrieli and Others, Robert King, Hyperion 1998. The rest of the material was recorded in London, as we learn from the booklet.

6I Cannons can be heard in: Italian Vespers I6I2, Robert Hollingworth, Decca 2012.

62 Deborah Howard, 'Recordings of Music Written for St. Mark's: An Architectural Historian's View', in: Word, Image, and Song, eds. Rebecca Cypess, Beth L. Glixon and Nathan Link, vol. I, Essays on Early Modern Italy, Rochester 2013, p. 89. 
paradoxically both as a disadvantage or an advantage, depending on the listener's expectations. On the recording of the Vespers i6io by the King's Consort (Hyperion 2007), David Allison writes: 'Those who listen while wearing their musicological hat may be disappointed to know that King's new version does not attempt to "situate" the Vespers in a particular church institution, nor to recreate a liturgical context for it - despite, or perhaps because of, all the modern contention about the particular feast Monteverdi had in mind when composing the collection'. ${ }^{63}$

The question also arises as to whether some musicians or producers deliberately conceal certain information in order to strengthen their message and sell their 'new', yet at the same time historically 'authentic', product. ${ }^{64}$ Do producers purposely not inform us about what is 'true' and what is 'constructed', in order not to disappoint and lose listeners? Or perhaps, in some instances, instead of marketing theory, we should refer to the process of myth creation? After all, 'the creation of myths must be removed from the public gaze in order for them to conserve their power to generate meaning. It would not be easy to believe in something knowing how it was made'. ${ }^{65}$ Posing the question in yet another light, is it not through 'little deceptions' that a given repertoire is able to reach a wider audience? A good example is Jean Richafort's Requiem, often advertised as 'in memoriam Josquin Desprez', although that is merely a musicological hypothesis far from being proven. ${ }^{66}$ The desire to promote a less familiar composer with the help of a recognisable name is sometimes counter-balanced by some 'musicological' concerns, which probably led to the introduction of square brackets enclosing the phrase 'in memoriam Josquin Desprez' in the re-issue of one album containing Richafort's work. ${ }^{67}$

The aim of this essay was to pose several questions to which I do not even attempt to find a single simple answer. Neither do I make any postulates in relation to musicologists or musicians and cover designers. It is also not my intention to fight with the myths we all create. I hope at least that this article will have a positive impact on music lovers and their perception of early music recordings not as 'historically authentic' products but as valuable attempts by contemporary musicians and scholars to excite our curiosity of the music of the past. I consider bold and sometimes provocative recordings to be equally as important and necessary as lucid and robust musicological polemics. Thanks to them, musicologists can listen to musicians, musicians can read musicologists, and listeners might never be lacking 'new works' by

63 David Allinson, 'Rediscovering Monteverdi, Sacred and Secular', Early Music 35 (2007) no. 2, p. 320.

64 Cf. N. Wilson, The Art of Re-enchantment, pp. I3, I54, 206.

65 '...proces tworzenia mitów musi być usunięty z widoku publicznego, by zachowały one swą sensotwórczą moc. Nie byłoby łatwo wierzyć w coś, o czym wiemy, jak jest zrobione’; M. Napiórkowski, Wtadza wyobraźni, p. 301 .

66 John Milsom, 'Sense and Sound in Richafort's Requiem', Early Music 30 (2002) no. 3, p. 447.

67 Richafort. Requiem [in memoriam Josquin Desprez], Paul Van Nevel, Harmonia Mundi 2013. There was no bracket in the first release of the recording in 2002. 
their favourite composers. And thanks to the efforts of Gardiner mentioned at the beginning, no one can say today that Monteverdi's Vespro della Beata Vergine was never performed in the church of St Mark in Venice - and by British musicians, to boot!

\section{BIBLIOGRAPHY}

Allinson, David. 'Rediscovering Monteverdi, Sacred and Secular.' Early Music 35, no. 2 (2007): 319-322.

Baroncini, Rodolfo and Marco di Pasquale, eds., Monteverdi a San Marco. Venezia I6I3-I643. Lucca: Libreria Musicale Italiana, 2020.

Bernstein, Jane A. 'Publish or Perish? Palestrina and Print Culture in I6th-Century Italy.' Early Music 35, no. 2 (2007): 225-236.

Bonta, Stephen. 'Liturgical Problems in Monteverdi's Marian Vespers.' Journal of the American Musicological Society 20, no. I (1967): 87-I06.

Bonta, Stephen. 'The Use of Instruments in Sacred Music in Italy 1560-1700.' Early Music I8, no. 4 (1990): 519-536.

Borghetti, Vincenzo. 'Purezza e trasgressione. Il suono del medioevo dagli anni cinquanta ad oggi.' Semicerchio 44 (20II): 37-54.

Burke, Peter. Eyewitnessing. The Uses of Images as Historical Evidence. Ithaca: Cornell University Press, 200I.

Butt, John. Playing with History. The Historical Approach to Musical Performance. Cambridge: Cambridge University Press, 2002.

Dixon, Graham. 'Monteverdi's Vespers of I610: "Della Beata Vergine”?' Early Music 15, no. 3 (1987): 386-90.

Edge, Kevin. The Art of Selling Songs. Graphics for the Music Business, 1690-199o. London: Futures Publications, 1991.

Fenlon, Iain. 'Venice. Theatre of the World.' In: The Renaissance. From the I470s to the End of the I6th Century, ed. Iain Fenlon, IO2-132. London: Palgrave Macmillan, I989.

Gembicki, Bartłomiej, 'Psalmy, mity i memy. Nieszpory w Wenecji od Willaerta do Gardinera.' $\mathrm{PhD}$ dissertation, Institute of Art of the Polish Academy of Sciences, 2020.

Haynes, Bruce. The End of Early Music. A Period Performer's History of Music for the Twenty-First Century. Oxford: Oxford University Press, 2010.

Howard, Deborah. 'Recordings of Music Written for St. Mark's. An Architectural Historian's View.' In: Word, Image, and Song, eds. Rebecca Cypess, Beth L. Glixon and Nathan Link. Vol. I, Essays on Early Modern Italy, 89-Ioo. Rochester: The University of Rochester Press, 2013 (= Eastman Studies in Music IOI).

Hucke, Helmut. 'Die fälschlich so genannte "Marien-Vesper" von Claudio Monteverdi.' In: Bericht über den Internationalen Musikwissenschaftlichen Kongress Bayreuth I98I, 295-305. Kassel: Bärenreiter, 1984.

Jones, Steve, and Martin Sorger. 'Covering Music: A Brief History and Analysis of Album Cover Design.' Journal of Popular Music Studies II-I2 (1999), 68-IO2.

Koldau, Linda Maria. Die Venezianische Kirchenmusik von Claudio Monteverdi. Kassel: Bärenreiter, 2005. 
Kurtzman, Jeffrey. 'Monteverdi's Missing Sacred Music. Evidence and Conjectures.' In: The Musicologist and Source Documentary Evidence: A Book of Essays in Honour of Professor Piotr Poźniak on His 7oth Birthday, eds. Zofia Fabiańska, Andrzej Sitarz, Piotr Wilk and Jakub Kubieniec, 187-208. Kraków: Musica Iagellonica, 2009.

Kurtzman, Jeffrey. The Monteverdi Vespers of I610. Music, Context, Performance. Oxford: Oxford University Press, 1999.

Kurtzman, Jeffrey. 'Monteverdi's Mass of Thanksgiving. Da Capo.' In: Fiori musicali: Liber amicorum Alexander Silbiger, eds. Claire Fontijn and Susan Parisi, 95-I28. Sterling Heights: Harmonie Park Press, 2010.

Łubocki, Jakub Maciej. Oktadka jako częsć dokumentu na przyktadzie ptyty gramofonowej w ujęciu bibliologicznym. Warszawa: Stowarzyszenie Bibliotekarzy Polskich, 2017.

Milsom, John. 'Sense and Sound in Richafort's Requiem.' Early Music 30, no. 3 (2002): $447-463$.

Moore, James H. 'The "Vespero Delli Cinque Laudate" and the Role of "Salmi Spezzati" at St. Mark's.' Journal of the American Musicological Society 34, no. 2 (I98I): 249-278.

Moore, James H. Vespers at St. Mark's. Music of Alessandro Grandi, Giovanni Rovetta, and Francesco Cavalli. Ann Arbor Mich.: UMI Research Press, I98I.

Napiórkowski, Marcin. Mitologia wspótczesna. Warsaw: Wydawnictwo Naukowe PWN, 2018. Napiórkowski, Marcin. Wtadza wyobraźni. Kto wymyśla, co zdarzyto się wczoraj? Warsaw: Wydawnictwa UW, 2014.

Noske, Frits. 'An Unknown Work by Monteverdi. The Vespers of St. John the Baptist.' Music \& Letters 66, no. 2 (1985): II8-I22.

Quaranta, Elena. Oltre San Marco. Organizzazione e prassi della musica a Venezia nel Rinascimento. Firenze: Olschki, 1998.

Rodini, Elizabeth. 'Describing Narrative in Gentile Bellini's Procession in Piazza San Marco.' Art History 2I, no. I (1998): 26-44.

Scherzinger, Martin. 'Toward a History of Digital Music. New Technologies, Business Practices and Intellectual Property Regimes.' In: The Cambridge Companion to Music in Digital Culture, eds. Nicholas Cook, Monique M. Ingalls and David Trippett, 33-57. Cambridge: Cambridge University Press, 2019.

Segal, Robert Alan. Myth. A Very Short Introduction. Oxford: Oxford University Press, 2004. Taruskin, Richard. Text and Act. Essays on Music and Performance. Oxford: Oxford University Press, 1995.

Torzecki, Mateusz. Oktadki ptyt. Rzecz o wizualnym uniwersum albumów muzycznych. Poznań: Instytut Kultury Popularnej, 2015.

Upton, Elizabeth. 'Concepts of Authenticity in Early Music and Popular Music Communities.' Ethnomusicology Review I7 (20I2), https://ethnomusicologyreview.ucla.edu/journal/ volume/I7/piece/591

Whenham, John. Monteverdi: Vespers (I610). Cambridge: Cambridge University Press, I997.

Wilson, Nick. The Art of Re-enchantment: Making Early Music in the Modern Age. New York:

Oxford University Press, 2013. 


\section{I „INNE” NIESZPORY}

W 1989 r. John Eliot Gardiner wykonał i zarejestrował w kościele św. Marka w Wenecji nieszpory maryjne Claudia Monteverdiego wydane w roku i6ıo. Mimo dedykacji druku dla papieża Pawła V, trzech lat różnicy między ukazaniem się zbioru a podjęciem pracy przez Monteverdiego na stanowisku maestro di cappella w kościele św. Marka oraz znacznej różnorodności stylistycznej zawartych w druku kompozycji, Gardiner, traktując dzieło Monteverdiego jako spójną całość, utrzymuje, że kościół św. Marka jest niejako docelowym miejscem jego powstania. Projekt Gardinera odegrał bez wątpienia istotną rolę w kształtowaniu wyobrażenia dzisiejszych odbiorców o nieszporach z i6ıo r., trwale zapisując się we współczesnej kulturze muzycznej. Świadczyć mogą o tym liczne wznowienia wspomnianego wyżej albumu, a zwłaszcza produkcje innych muzyków, które łączą te nieszpory z kościołem św. Marka.

Niniejszy artykuł dotyczy pojęcia „nieszpory Monteverdiego” we współczesnej fonograficznej recepcji twórczości kompozytora. Pojęcie to oznacza zarówno utwory składające się na wydane w i6ıo r. Vespro della Beata Vergine Claudia Monteverdiego, jak i współczesne kompilacje utworów kompozytora opatrywanych przez muzyków, muzykologów i producentów określeniem „nieszpory”. Bogaty zasób zachowanych w bibliotekach i archiwach kompozycji nieszpornych wciąż znacznie przewyższa liczbę ich nagrań czy wykonań. Same zaś nieszpory Monteverdiego, stanowią większość wyprodukowanych dotąd dźwiękowych zapisów polifonicznego repertuaru nieszpornego różnych autorów z całego XVII w. i tym samym ważny punkt odniesienia. Analizowany materiał dyskograficzny stanowi ok. 500 albumów (nie tylko z muzyką nieszporna) wydanych w 1. 1952-2019. Skupiając się na zawartych treściach ikonograficznych i typograficznych w projektach graficznych albumów muzycznych, autor stawia pytania o sposób kształtowania się współczesnych wyobrażeń na temat tego repertuaru oraz postaci i miejsc z nim związanych w kontekście fonografii.

\section{Barttomiej Gembicki}

Keywords / słowa kluczowe: early music recording / nagrania muzyki dawnej, Claudio Monteverdi, Venice / Wenecja, San Marco / kościół św. Marka, John Eliot Gardiner, HIP, myths / mity, Italian music / muzyka włoska, Vespers / nieszpory

Bartłomiej Gembicki, PhD, works for the Institute of Art (Department of Musicology) at the Polish Academy of Sciences in Warsaw. In the framework of the 'Sound Memories' project (HERA) he prepared his PhD thesis entitled Psalms, Myths and Memes: Vespers in Venice from Willaert to Gardiner. In his research he focuses on issues such as myth and meaning in music and musicology as well as early-music reception and record production. He is also an assistant editor in the editorial series Monumenta Musicae in Polonia, which is dedicated to critical editions of Polish musical sources.

b.gembicki@gmail.com 